\title{
腎不全を呈した多発性骨髄腫の検討
}

\author{
小木幸人今田聰雄栗田孝 \\ 近畿大学附属病院人工透析部
}

(昭和 63 年 11 月 7 日受付)

key words：多発性骨髄腫，慢性腎不全，急性腎不全，無 Ca 血液濾過，血漿交換

〈要旨〉

多発性骨髄腫に合併する腎障害は，炎の予後を左右する大きな因子だと考えられる．当院で 1977 年から 1987 年ま での 11 年間に多発性骨髄腫と診断された 56 例を対象として, 初診時の腎障害の有無で生存率を比較してみた。初診 時の血液尿素窒素 (BUN) 值が $25 \mathrm{mg} / \mathrm{d} /$ 末満の症例と以上の症例の 1 年生存率, 3 年生存率を比較した。 弚のいず れにおいても BUN が $25 \mathrm{mg} / \mathrm{d} /$ 以上の症例の生存期間は $1 / 2$ 以下で, 有意 $(\mathrm{p}<0.005)$ に短縮しており, 4 年以 上の生存例はなかった。乥こで腎障害が, 多発性骨髄腫の予後におよぼす影響を調べた。 すなわち, 対象の中から血 液浄化法が施行された 11 例を腎不全群として, 腎不全の発症率, 腎不全を発症させた因子, 生存期間, および生存率 を 45 例の非腎不全群を対照として比較検討した. M蛋白の型別での腎不全の発症率は IgG が $10.8 \%$, IgD が $66.6 \%$, Bence-Jones (B-J) が $62.5 \%$ であった. 腎不全群と非腎不全群の初診時の臨床検査値の比較では, 前者が Ht 值およ び24 時間 creatinine clearance 值が有意に低值, BUN, creatinine および尿酸值が有意に高值であった. 生存期間で は腎不全群が 16.2 か月であったのに対し非腎不全群は 31.9 か月で, 腎不全群が約 $1 / 2$ であった. しかし, 腎機能の 回復した症例では 27.0 か月であり非腎不全群と同等であった. 一方, 高 $\mathrm{Ca}$ 血症による急性腎不全の 1 例は無 $\mathrm{Ca}$ hemofiltration で, また高粘稠度症候群による2 例は血漿交換によって腎機能の回復が認められた。

多発性骨髄腫の 30〜 50\%は，弚の経過中に何らかの腎障害を合併するといわれ，予後を決める重要な因子である. したがって本症の長期生存のためには, 腎障害の発症あるいは腎機能を増悪させる因子を知り, 早い時期から予防対 策をたてること, および発症した腎不全に対しては, 血液浄化療法を病期, 病態にあわせて積極的に施行することが 重要だと思われた。

\section{A study of multiple myeloma with renal failure.}

\section{Yukito Koghi, Akio Imada, M. D., Takashi Kurita, M. D.}

Department of Artificial Dialysis, Kinki University Hospital.

Hemopurification for renal failure (RF) as a complication of multiple myeloma was investigated as to efects and prognosis. Of 56 patients diagnosed with multiple myeloma during the period from 1977 to 1987, 11 underwent hemopurification. The 56 were classified by M-protein type ; the incidence of RF and survival rate were determined for each type. Data from the initial clinical examinations were also considered. The incidence was $14.3 \%$ for chronic renal failure (CRF) and $5.4 \%$ for acute renal failure (ARF). RF occurred in $4(10.8 \%)$ of 37 IgG type cases, $2(66.6 \%)$ of $3 \operatorname{lgD}$ type and $5(62.5 \%)$ of 8 Bence-Jones type, but did not occur in any of the $8 \lg A$ type cases. Comparison of survival rate between the RF complicated and noncomplicated groups yielded a significantly $(p<0.005)$ smaller figure for the RF complicated group (about $1 / 2$, that of the other group). However, even within the RF group, longer survival was noted in patients who recovered renal function, than in those who did not. It was concluded that patients suffering from multiple myeloma complicated by RF must undergo hemopurification to the extent appropriate for the pathologic condition, as well as treatment for multiple myeloma, to increase survival time.

小木 幸人 近畿大学附属病院人工透析部

₹ 589 大阪府大阪狭山市大野東 377-2(0723-66-0221)
緒言

多発性骨髄腫に合併する腎障害は腫瑒化した形質細胞 の産生する単一クローン性免疫グロブリン (M蛋白) と, 
表 1 対象症例

\begin{tabular}{|c|c|c|c|c|c|c|c|c|c|}
\hline No & 性別 & 年齢 & \multicolumn{2}{|c|}{ 初発症状 } & M蛋白 & 腎不全 & 転㷌 & 生存期間 & 死因 \\
\hline 1 & 男 & 58 & \multicolumn{2}{|c|}{ 全身僚怠感 } & IgG-K & ARF & & 29 & \\
\hline 2 & 男 & 63 & \multicolumn{2}{|c|}{ 全身倦怠感 } & IgG-L & $\mathrm{CRF}$ & 死亡 & 28 & 敗血症 \\
\hline 3 & 男 & 49 & \multicolumn{2}{|c|}{ 易 疲労 感 } & IgG-K & $\mathrm{CRF}$ & 死亡 & 8 & 心不全 \\
\hline 4 & 女 & 67 & 腰 & 痛 & IgG-L & $\mathrm{CRF}$ & 死亡 & 24 & 感染症 \\
\hline 5 & 男 & 43 & 腰 & 痛 & IgD-L & $\mathrm{CRF}$ & 死亡 & 6 & 肺出血 \\
\hline 6 & 男 & 50 & 関 節 & 痛 & IgD-L & $\mathrm{CRF}$ & 死亡 & 20 & 敗血症 \\
\hline 7 & 男 & 65 & \multicolumn{2}{|c|}{ 労作時腰痛 } & B-J-L & $\mathrm{ARF}$ & & 23 & \\
\hline 8 & 女 & 65 & 貧 & 血 & B-J-L & $\mathrm{ARF}$ & & 29 & \\
\hline 9 & 男 & 66 & 腰 & 痛 & B-J-L & $\mathrm{CRF}$ & 死亡 & 2 & 肺 炎 \\
\hline 10 & 男 & 61 & 発 & 熱 & B-J-L & $\mathrm{CRF}$ & 死亡 & 2 & 敗血症 \\
\hline 11 & 女 & 42 & 貧 & 血 & B-J-L & $\mathrm{CRF}$ & 死亡 & 3 & 脳梗塞 \\
\hline
\end{tabular}

その排泄に密接な関係があると言われている，M蛋白が 腎障害を惹起する機序としては，その増加による血液粘 稠度の亢進による微小循環障害や，M蛋白そのものの腎 毒性，あるいは濾過された $\mathrm{M}$ 蛋白が円柱を形成し尿細管 を機械的に閉塞し腎機能を障害することなどが考えられ ている，さらに，2次的に起こる高 $\mathrm{Ca}$ 血症や高尿酸血 症による $\mathrm{Ca}$ 塩, 尿酸塩の沈着も腎障害の原因になりう るようである ${ }^{1,2)}$. これらの腎障害の合併は直接の死因に なることもあり，一般的に腎障害合併例の予後は不良と いわれている.しかし, 近年では化学療法の確立ととも に支持療法の 1 つである血液浄化療法が進歩, 発展した ことで，多発性骨髄腫に合併した腎不全例に対してもそ れらが積極的に施行されはじめ, 腎機能の回復をみた 例 ${ }^{3,4)}$ や，長期間血液浄化療法を施行した症例も報告され ている ${ }^{5,6)}$. 今回，われわれは血液浄化療法を必要とした 多発性骨髄腫に合併した腎不全例を, 腎不全の発症率, およびその予後について非腎不全例と比較し検討したの で報告する。

\section{対象・方法}

1977 年から 1987 年の 11 年間に本院で多発性骨䯣腫 と診断された年齢 $35 \sim 88$ (平均 $61.6 \pm 11.6$ ) 歳の男性 36 例，女性 20 例計 56 例のうち腎障害を合併し血液浄化療 法を施行した年齢 $42 \sim 67$ (平均 $57.9 \pm 10.5$ ) 歳の男性 8 例，女性 3 例計 11 例を対象（腎不全群）とした（表 1 ）。 また血液浄化療法未施行群の年齢 $35 \pm 88$ (平均 $62.7 \pm$ 11.7 ) 歳の男性 28 例, 女性 17 例の計 45 例を対照（非腎 不全群）とした。

全症例の腎障害の有無を, BUN 值 $25 \mathrm{mg} / \mathrm{d} l$ 未満と 以上に分けてそれらの生存率を 1 年, 3 年, 5 年以上で 比較した。 そして, 対象とした症例をM蛋白の型別に分 けて, その占める割合, 腎不全の発症率, 死亡率および 生存期間を比較した。また，腎不全合併の有無および腎 機能回復例の生存期間も比較した。さらに, 腎不全を発
生させる因子としてへマトクリット $(\mathrm{Ht})$ 值, 血液尿素 窒素 (BUN) 值, 血清 creatinine 值, 血清尿酸 (UA) 值, 血清 $\mathrm{Ca}$ 值, 24 時間 creatinine clearannce $(24 \mathrm{CCr})$, M蛋白量, 骨髄中の plasma cell 数を選び, これらの初 診時の值を腎不全例と非腎不全例で比較した。急性腎不 全例のうち高 $\mathrm{Ca}$ 血症によるものには無 $\mathrm{Ca}$ 置換液を作 製し 1 回 $10 l$ で hemofiltration を $3 \sim 5$ 回施行した. 一方, 高粘稠度症候群によるものには体重の $5 \%$ を指標 として置換液量を決め血漿交換，および double filtration plasmapheresis (DFPP) を $3 \sim 4$ 回施行した.

\section{結果}

1. M蛋白の型と予後

全症例 56 例をM蛋白の型でわけてその占める割合, 腎 不全の発症率, 死亡率および生存期間を表 2 に示した。 M蛋白別の割合では IgG が 37 例で $66.0 \%, \operatorname{IgA}$ が 8 例 で $14.3 \%$, IgD が 3 例で $5.4 \%$, Bence-Jones (B-J) が 8 例で $14.3 \%$ であった。これらのうちで腎不全の発症率 は IgG が 4 例で $10.8 \%, \operatorname{IgD}$ が 2 例で $66.6 \%, \mathrm{~B}-\mathrm{J}$ が 5 例で $62.5 \%$ でった. IgD, B-J は IgG の腎不全発症 率に比べて高率であった. IgA には発症を認めなかった。 全症例の中の死亡例は $\operatorname{IgG}$ が 15 例, IgA が 3 例, IgD が 2 例そして B-J が 7 例で, 死亡率はそれぞれ 40.5\%, $37.5 \%, 66.6 \%$ そして $87.5 \%$ でり IgD，B-J の死亡率 は他の型の $1.5 \sim 2.0$ 倍であった. また, 骨髄腫と診断さ れてからの生存期間は IgG が $35.5 \pm 23.5$ か月, IgA が $34.5 \pm 23.6$ か月, $\operatorname{IgD}$ が $16.0 \pm 7.1$ か月および B-J が $15.5 \pm 12.7$ か月であり, 生存期間は IgD, B-J が他の型 短縮していた。

\section{2. 初診時 BUN と生存率}

腎障害の有無を BUN 值 $25 \mathrm{mg} / \mathrm{d} l$ 未満と以上で分け てその生存率を $0 \sim 12 ， 13 \sim 36,37 \sim 60 ， 61$ か月以上の 期間で調べたものを生存月数で現して表 3 に示した。初 診時の $\mathrm{BUN}$ が $25 \mathrm{mg} / \mathrm{d} l$ 未満の非腎不全例では 1 年生 
表 2 M蛋白の型と予後

\begin{tabular}{crrrrrr}
\hline \multirow{2}{*}{ Type } & 全症例 & 非腎不全 & 腎不全* & 寛 解 & 死 亡 & 生存期間** \\
\cline { 2 - 7 } & $\mathrm{n}(\%)$ & $\mathrm{n}(\%)$ & $\mathrm{n}(\%)$ & $\mathrm{n}(\%)$ & $\mathrm{n}(\%)$ & (month) \\
\hline Ig G & $37(66.0)$ & $33(89.2)$ & $4(10.8)$ & $22(59.5)$ & $15(40.5)$ & $35.5 \pm 23.5$ \\
Ig A & $8(14.3)$ & $8(100)$ & $0(0)$ & $5(62.5)$ & $3(37.5)$ & $34.5 \pm 23.6$ \\
Ig D & $3(5.4)$ & $1(33.3)$ & $2(66.6)$ & $1(33.3)$ & $2(66.6)$ & $16.0 \pm 7.1$ \\
B-J & $8(14.3)$ & $3(37.5)$ & $5(62.5)$ & $1(12.5)$ & $7(87.5)$ & $15.5 \pm 12.7$ \\
\hline
\end{tabular}

* : 血液浄化療法を施行したもの ${ }^{* *}$ : 骨髄腫と診断されてから死亡までの期間

表 3 初診時尿素窒素值と生存率

\begin{tabular}{lcccccc}
\hline & $\mathrm{n}$ & $\sim 12$ & $13 \sim 36$ & $37 \sim 60$ & $61 \sim$ & (月) \\
\hline $\mathrm{BUN}<25 \mathrm{mg} / \mathrm{d} l$ & 31 & 93.5 & 45.2 & 25.8 & 14.3 & \\
$\mathrm{BUN} \geqq 26 \mathrm{mg} / \mathrm{d} l$ & 25 & 40.0 & 10.0 & 0 & 0 & (\%) \\
\hline
\end{tabular}

平均生存率: $\mathrm{BUN}<25 \mathrm{mg} / \mathrm{d} l \quad 41.1 \pm 23.7$ 名月

$\mathrm{BUN} \geqq 26 \mathrm{mg} / \mathrm{d} l \quad 15.7 \pm 15.4$ 只月

表 4 非腎不全群と腎不全群の多発性骨髄腫の 確定診断後の生存期間

\begin{tabular}{lrcc}
\hline & $\mathrm{n}$ & 透析期間 & 生存期間 \\
\hline 非腎不全 & 45 & $(-)$ & $31.9 \pm 24.0$ \\
腎不全 & 11 & $15.3 \pm 4.8$ & $16.2 \pm 12.2$ \\
(機能回復) & 3 & $0.3 \pm 0.1$ & $27.0 \pm 2.8$ \\
\hline
\end{tabular}

存率は $93.5 \%$ であり 3 年では $45.2 \%$ であった. 3 年後で も約半数の症例の生存が認められた。一方初診時 BUN が $25 \mathrm{mg} / \mathrm{d} l$ 以上とすでに腎障害をきたしていた症例で は 1 年生存率は $40 \%, 3$ 年生存率は $10 \%$ と低く 4 年以上 の生存例は認められなかった. また, BUN $25 \mathrm{mg} / \mathrm{d} l$ 末 満の平均生存期間は $41.1 \pm 23.7$ か月であったのに対し て $25 \mathrm{mg} / \mathrm{d} l$ 以上では $15.7 \pm 14.7$ か月であった.

\section{3 . 非腎不全群と腎不全群の生存期間}

非腎不全群, 腎不全群および腎機能回復例の透析期間 と生存期間を表 4 に示した. 非腎不全群の生存期間は $31.9 \pm 24.0$ か月であったが, 腎不全群では $16.6 \pm 12.2$ か月であり, 後者の生存期間は約 $1 / 2$ に短縮していた。 しかし, 腎機能が回復した例では $27.0 \pm 2.8$ か月であり 非腎不全群とほぼ同じであった。

\section{4. 非腎不全群と腎不全群の初診時臨床検査値}

非腎不全群と腎不全群の初診時の臨床検査値を比較し 表 5 に示した。非腎不全群と腎不全群の初診時の $\mathrm{Ht}$ 值 は $27.0 \pm 7.2 \%, 22.6 \pm 6.7 \%(\mathrm{p}<0.001), 24 \mathrm{Ccr}$ は 48 . $5 \pm 22.0 \mathrm{ml} / \mathrm{min}, 24.2 \pm 20.9 \mathrm{ml} / \mathrm{min}(\mathrm{p}<0.01)$ であり腎 不全群の方が有意に低值を示していた。一方, BUN は $24.7 \pm 18.4 \mathrm{mg} / \mathrm{d} l, \quad 56.5 \pm 31.8 \mathrm{mg} / \mathrm{d} l \quad(\mathrm{p}<0.001)$, creatinine は $1.5 \pm 1.4 \mathrm{mg} / \mathrm{d} l, 6.8 \pm 6.0 \mathrm{mg} / \mathrm{d} l \quad(\mathrm{p}<0$.

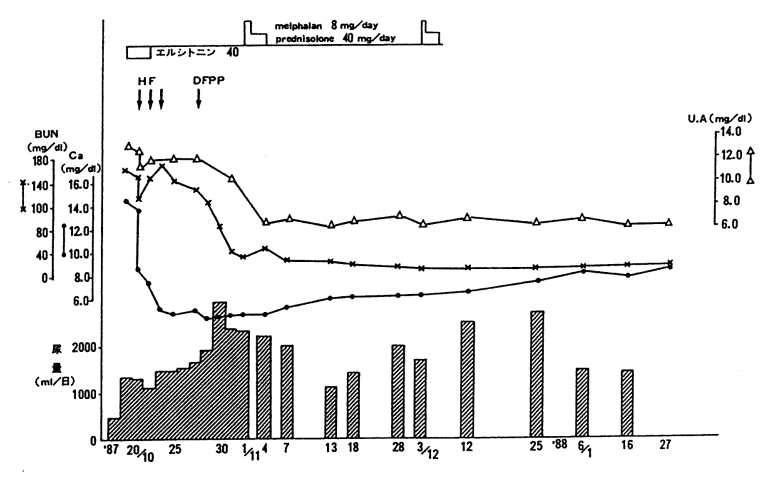

図 1 高 $\mathrm{Ca}$ 血症による急性腎不全に無 $\mathrm{Ca} \mathrm{HF}$ を施行した症例の経過

$001)$, 尿酸值は $6.5 \pm 2.3 \mathrm{mg} / \mathrm{d} l, 8.8 \pm 3.2 \mathrm{mg} / \mathrm{d} l \quad(\mathrm{p}<0$. 01）と腎不全例の方が有意に高值を示していた.しかし， 血清 $\mathrm{Ca}$ 值などその他の検査値には有意の差は認められ なかった。

5. 高 $\mathrm{Ca}$ 血症による急性腎不全例

図 1 に高 $\mathrm{Ca}$ 血症による急性腎不全に無 $\mathrm{Ca}$ の置換液 を用いて hemofiltration を施行し, 腎機能の回復を認め た症例の経過を提示した. 症例：65 歳男性, IgA-L 型骨 髄腫. 入院時に BUN $85 \mathrm{mg} / \mathrm{d} l$, creatinine $2.7 \mathrm{mg} / \mathrm{d} l$, 尿酸 $13.4 \mathrm{mg} / \mathrm{d} l$, 血清 $\mathrm{Ca} 16.6 \mathrm{mg} / \mathrm{d} l$ と高度の高 $\mathrm{Ca}$ 血 症と腎機能低下がみられた.入院後エルシトニン 40 単位 の投与と補液が行われたが血清 $\mathrm{Ca}$ 值は $14.3 \mathrm{mg} / \mathrm{d} l$ ま でしか低下しなかった。一方, BUN が $165 \mathrm{mg} / \mathrm{d} l$, creatinine が $3.8 \mathrm{mg} / \mathrm{d} l$ と上昇し高 $\mathrm{Ca}$ 血症による急性 腎不全と考えられたため高 $\mathrm{Ca}$ 血症と高窒素血症の改善 を目的として無 $\mathrm{Ca}$ の置換液を作製し $10 l /$ 回で hemofiltration を施行した. 3 回の施行によって血清 Ca は 9.1 $\mathrm{mg} / \mathrm{d} l$ まで低下し高 $\mathrm{Ca}$ 血症による消化器症状も消失し た.また, 施行 1 週間後には BUN $36 \mathrm{mg} / \mathrm{d} l$, creatinine $1.3 \mathrm{mg} / \mathrm{d} l$, 尿酸 $6.2 \mathrm{mg} / \mathrm{d} l$ と急性腎不全状態を脱した.

6. 高粘稠度症候群による急性腎不全例

図 2 に高粘稠度症候群に対して血漿交換と血液透析を 
表 5 非腎不全群と腎不全群の初診時の臨床検査値

\begin{tabular}{lccccc}
\hline & $\mathrm{n}$ & $\mathrm{Ht}(\%)$ & $\mathrm{BUN}(\mathrm{mg} / \mathrm{d} l)$ & $\mathrm{Cr}(\mathrm{mg} / \mathrm{d} l)$ & $\mathrm{UA}(\mathrm{mg} / \mathrm{d} l)$ \\
\hline 非堅不全 & 45 & $27.0 \pm 7.2$ & $24.7 \pm 18.4$ & $1.5 \pm 1.4$ & $6.5 \pm 2.3$ \\
腎不全 & 11 & $22.6 \pm 6.7$ & $56.5 \pm 31.8$ & $6.8 \pm 6.0$ & $8.8 \pm 3.2$ \\
\hline \multicolumn{5}{r}{} \\
\hline
\end{tabular}

施行し腎機能の回復を認めた症例の経過を提示した。

症例 : 58 歳男性, IgG-K 型骨髄腫. 入院後化学療法が 施行されていたが 3 か月を経過した後, $\operatorname{IgG}$ が $9.0 \mathrm{~g} / \mathrm{d} l$ まで上昇し出血傾向と精神神経症状を主症状とする過粘 稠度症候群が発現した。 また尿量は $460 \mathrm{~m} l /$ 日と減少し, $\mathrm{BUN}$ が $72 \mathrm{mg} / \mathrm{d} l$ と上昇, $\mathrm{ARF}$ の発生が考えられた。 そこで IgG を除去し血液粘稠度を下げることを目的と して体重の $5 \%$ の血漿量を置換することを指標として血 漿交換を施行したそその結果 $\operatorname{IgG}$ は $2.0 \mathrm{~g} / \mathrm{d} l$ まで低下 し出血傾向, 精神神経症状は消失した.また, 尿量は 3100 $\mathrm{m} l /$ 日に増加したがその後再び $1200 \mathrm{~m} l /$ 日, $800 \mathrm{~m} l /$ 日, $500 \mathrm{~m} l /$ 日と減少し $\mathrm{BUN}$ が $106 \mathrm{mg} / \mathrm{d} l$ と上昇して高窒 素血症が増悪したため, 血液透析を 2 回施行した。 2 回 目の血液透析後より漸次尿量は増加し, BUN も減少し て腎機能の回復が認められた。

\section{考察}

多発性骨髄腫はその経過中に 30〜 50\%の症例に何ら かの腎障害を合併するといわ机，腎障害そのものが直接 の死因になることもあり, 腎障害の合併は予後を極めて 不良なものとしている ${ }^{11}$. Carbon ら”はその生存期間を BUN $20 \mathrm{mg} / \mathrm{d} l$ 以下では 37 か月, BUN $40 \mathrm{mg} / \mathrm{d} l$ 以上 では 2 か月と報告している。そこで，一般的には腎障害 の有無は $\mathrm{BUN} \geqq 30 \mathrm{mg} / \mathrm{d} l$, 血清 creatinine $\geqq 2.0 \mathrm{mg} / \mathrm{d} l$ を指標にして分けられているが,われわれは, BUNを 25 $\mathrm{mg} / \mathrm{d} l$ を境とした腎障害の有無で生存率を比較した。初 診時すでに腎障害を有していた例の方が 1 年生存率, 3 年生存率とも腎障害のなかった例の $1 / 2$ となり 4 年以上 の生存例はみられなかった。 そして, 平均生存期間は 15.7 かで腎障害のなかった例に比べて $1 / 2$ 以下で あった。しかし, Carbon らの報告に比べれば腎不全を合 併した症例の生存期間は 7 倍に延長していた。これは, BUN を $25 \mathrm{mg} / \mathrm{d} l$ で分けたことも関係していると思わ れるが, 腎不全に対する血液浄化療法の効果が寄与して いるものと考えられた.

今回, われわれの施設では過去 11 年間に 56 例が多発 性骨髄腫と診断され, そのうちの 11 例が血液浄化療法を

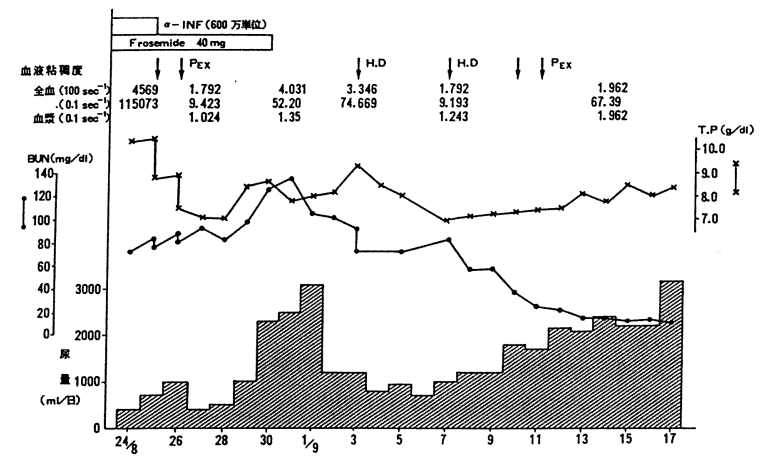

図 2 高粘稠度症候群による急性腎不全に血漿交 換と血液透析を施行した症例の経過

必要とするほどの腎不全の合併がみられた。腎不全の合 併例の男女比は 2.6：1であり骨髄腫のそれと同様であ り腎不全発症に性差はみられなかった。腎不全の発症率 は $20.0 \% て ゙ ~ H e p t i n s t a l 1^{9)}$ の 30\%に比べ低率であった。 また, 急性腎不全の発症率は 5.4\%であったが, DeFronzo ら $^{10)}$ の急性腎不全の発症率 $7 \sim 10 \%$ に比べるとやや 低率であった。これは，われわ机が血液浄化療法を施行 した症例を腎不全としたためと考えられる。腎不全の合 併は IgD と Bence-Jones (B-J) が $60 \%$ 以上であり，死 亡率も同様であった。これは Jancelewicz ら ${ }^{11)}$ と同様の 結果であり, IgD, B-J に発症率, 死亡率ともに高かった。 また, $\operatorname{Ig} A$ に発症が見られなかったのは症例数が少ない ためでもあるが真の原因は不明である。腎不全を合併し た症例の平均生存期間は 16.2 か月と非合併例に比べる と約 $1 / 2$ と短縮していた。しかし, 血液浄化療法を施行 し腎機能が回復した例では 27.0 か月と非合併例とほほ 同程度となっていた，多発性骨髄腫の予後を推測するた めの指標として Witts ら ${ }^{15}$ は BUN がよいとし, Matzner $ら^{16)}$ は年齢と BUN が, また, 中辻 ${ }^{17) ら は ~} \mathrm{Hb}$ が最 も有用な予後決定の指標であると述べている。われわれ は腎不全の合併を予測するための指標を初診時の臨床検 査值で検討してみた。すなわち腎不全合併例と非合併例 で Ht, BUN, creatinine, UA を比較したところ,これら 
には有意な差を認めた。したがって初診時にこれらの因 子が低下あるいは上昇していれば腎不全発症の危険性が 大きいので注意が必要だと思われた。

今回われわれは高 $\mathrm{Ca}$ 血症による急性腎不全に対して 無 $\mathrm{Ca}$ の置換液を用いた hemofiltration を施行し腎機能 の早期の回復をみた。また, 高粘稠度症候群による急性 腎不全には血墏交換を試みよい結果をえたことより，高 $\mathrm{Ca}$ 血症の急性期には無 $\mathrm{Ca}$ の hemofiltration で機械的 に Ca の除去を行うことが有効だと考えた。一方，高粘 稠度症候群に対しては Solomon ら ${ }^{12}$ が血漿交換を応用 して以来その有用性が報告されている，2症例の経験で はあるが血漿交換により血中M蛋白が除去されたことで 腎機能の回復がえられ有用な治療法だと考えられた。以 上のことから, 多発性骨髄腫に対しては適切な化学療法 などを行うと同時に腎不全の発症を予測しこれを未然に 防ぐこと，および発症した腎不全には病態に合った血液 浄化療法の施行が多発性骨髄腫の予後を良好なものにす ると考えられた。

\section{結語}

多発性骨髄腫はM蛋白の型にもよるが腎障害を合併し やすく，一旦合併するとその予後は不良だといわれてい る. 腎不全の発症あるいはその進行は BUN が指標とな り BUN の值によって腎不全の発症を未然に防ぐこと. そして発症した腎不全に対しては支持療法である血液浄 化法を病期，病態にあわせて積極的に施行することで腎 不全を合併した症例でも長期生存を可能にするものと思 われた。

本論文の要旨は第 33 回日本透析療法学会において発表した

\section{文献}

1）大沢源吾，木下康民：多発性骨髄腫障。総合臨床 $25: 1783-1790,1962$

2）堀内篤：血液疾患と腎障害. 腎と透析 13 ： 661-667, 1982

3) Misiani R, Remuzzi G, Bertani T, Lincini R, Levoni P, Grippa A, Mecca G : Plasmapheresis in the treatment of acute renal failure in multiple myeloma. Am J Med 66 : 684-688, 1979

4）辻 幸太, 星野賢一郎, 中瀬一則, 山口拓子, 伊藤 質, 宮西永樹: 多発性骨髄腫の血漿交換法. 臨床血 液 $27 ： 1226-1229 ， 1986$

5) Boyce NW, Thomson NM, Holdsworth SR, Atkins RC: "Long-term" survival in light-chain myeloma with dialysis therapy alone. Aust NZ J Med $14: 676-677,1984$
6）瓜生康平, 海津嘉蔵, 阿部理一郎, 織田 進, 千葉 省三，江藤澄哉，鈴木秀郎：長期間（26 か月）腹膜 透析を施行しえた多発性骨髄腫の 1 例。産業医科大 学雑誌 $6: 391-396,1984$

7) Carbon PP, Kellerhouse LE, Gehah BA: Plasmacytic myeloma. A study of the relationship of survival to various clinical manifestation and anomalous protein type in 112 patients. Am J Med 42 : 937-948, 1967

8) Cosio FG, Pence TV, Shapiro FL, Kjellstrand $\mathrm{CM}$ : Serve renal failure in multiple myeloma. Clin Nephrol 5 : 206-210, 1981

9) Heptinstall RH : Pathology of the Kidney. 2nd Ed, 753-766, Little, Brown \& Co Boston, 1974

10) DeFronzo RA, Humphrey RL, Wright JR, Cook $\mathrm{CR}$ : Acute renal failure in multiple myeloma. Medicine 54 : 209-233, 1975

11) Jancelewicz $Z$, Takatsuki $K$, Sugai $S$, Pruzanski $\mathrm{W}:$ IgD myeloma. Review of 133 cases. Arch Intern Med $135: 87-93,1975$

12) Solomon A, Fahey JL : Plasmapheresis therapy in macroglobulinemia. Ann Int Med $58: 789-800$, 1963

13）小川正時, 石塚太一, 石川正道, 嵐 賢治, 相引利 行, 横山 登, 肥後 理: 血漿交換が著効を奏した IgD $(\mathrm{K})$ 型 myeloma の 1 症例. 臨床血液 23 : 237-240, 1982

14）赤保内良和，阿部 敬，平田博三，伴 紀宏，野村 孝幸, 大嶋哲夫, 管 充生, 谷内 昭: Bence-Jones 蛋白腎症に起因すると考えられる急性腎不全に血漿 交換が著効を示した $\operatorname{IgD}(\lambda)$ 型骨髄腫の 1 例. 臨床 血液 25：176-181，1984

15) Medical Research Council's Working Party for therapeutic trials in leukaemia: Report on the first myelomatosis trial. Part 1. Analysis of presenting features of prognostic importance. $\mathrm{Br}$ J Heamatol $24:$ 123-139, 1973

16) Matzner $Y$, Benbassat J, Polliack A : Prognostic factors in multiple myeloma. Acta Heamatol 60 : 257-268, 1978

17）中辻理子, 松本 昇, 加来浩平, 広重幸雄, 織田 進, 篠原健次, 中島弘二, 小林勝昌, 矢賀 健, 藤井真 也, 三輸史朗, 亀井敏明, 長沢孝明, 谷 茂樹: 多 発性骨髄腫。臨床血液 $21 ： 347-355,1980$ 